\title{
Chapter 18 \\ Cute, Creepy, or Crispy-How Values, \\ Attitudes, and Norms Shape Human \\ Behavior Toward Bats
}

\author{
Tigga Kingston
}

\begin{abstract}
Bat populations around the world are declining as a consequence of human activities. Bat conservation thus hinges on changing human behavior, but to do so, we must understand the origins and drivers of the behavior. As natural scientists, most bat biologists lack the knowledge and training to implement rigorous studies of the human dimensions of bat conservation, yet such studies are needed to guide successful intervention. As we travel through the Anthropocene, it is critical that bat conservation biologists adopt an interdisciplinary approach and work with researchers from the social sciences who hold these skills and knowledge. To facilitate conversation and collaboration with conservation social scientists, I review the key theoretical and empirical perspectives on human behavior toward wildlife and report on studies of bats in these contexts wherever possible. I also recommend ways in which bat biologists can use some of this knowledge to enhance less structured or opportunistic outreach efforts encountered during our research activities.
\end{abstract}

\subsection{Introduction}

Human activities have wrought such intensive and extensive environmental changes to our planet that we now witness the dawn of the Anthropocene-the human epoch. The Anthropocene is not being kind to bats; populations are declining around the world (Voigt and Kingston 2016) in response to land-use change

\footnotetext{
T. Kingston $(\bowtie)$

Department of Biological Sciences, Texas Tech University, Lubbock, TX, USA

e-mail: tigga.kingston@ttu.edu
} 
and management practices (Law et al. 2015; Meyer et al. 2015; Korine et al. 2015; Williams-Guillén et al. 2016), urbanization and intensification (Altringham and Kerth 2015; Arnett et al. 2015; Jung and Threlfall 2015; Rowse et al. 2016), disturbance and loss of roosts (Furey and Racey 2015; Law et al. 2015; Voigt et al. 2016), and direct exploitation for bushmeat and medicine (Mildenstein et al. 2016). As human populations grow and encroach on remaining bat habitat, human-bat interactions are increasing, often with negative consequences for both parties through disease relationships (Schneeberger and Voigt 2016), occupation of human dwellings (Voigt et al. 2016), and conflict over fruit crops (Abdul Aziz et al. 2015).

The Anthropocene is named for us, and solutions to our environmental problems rest with us, as Mascia et al. (2003) so concisely put it: "Biodiversity conservation is a human endeavor: initiated by humans, designed by humans, and intended to modify human behavior"-(Mascia et al. 2003, p. 650). Bat conservation is no different from any other aspect of biodiversity conservation in this regard; attempts to reduce the many threats to bats ultimately hinge on changing peoples' behavior (Stern 2000; Ehrlich and Kennedy 2005; Schultz 2011; St John et al. 2013; Veríssimo 2013; Clayton and Myers 2015). "People" may range from bat hunters in rural villages to government officials or politicians in administrative centers, but as stakeholders in the issues surrounding bats, they must be motivated to change their actions and decisions (Menon and Lavigne 2006). How do we determine the stakeholders involved and how do we then change people's minds and behavior? The scientific training of most bat biologists leaves us illequipped both practically (St John et al. 2010, 2014) and philosophically (Moon and Blackman 2014) and often extraordinarily naïve, when it comes to dealing with people. Surely, if we share our knowledge and "educate" people, they will change their ways. Hunters in Ghana and Indonesia will be so impressed by the importance of bats as pollinators of their favorite fruit, or so fearful of disease risk, that they will stop hunting them. US politicians will mandate turbine cut-in speeds that reduce bat fatalities once they appreciate the critical role that bats play in the suppression of agricultural insect pests. Home owners will learn to live with their seasonal "attic bats" because they are keeping down the summer mosquito population.

Unfortunately, providing people with environmental knowledge alone is rarely enough to promote conservation behavior, and there is an enormous body of research from the social sciences, primarily from social psychology (St John et al. 2010; Teel et al. 2015), addressing the theoretical constructs behind behavior change. These constructs have provided frameworks for empirical assessments of attitudes and behaviors toward the environment and wildlife, and new disciplines such as human dimensions of wildlife (Manfredo 2008; Decker et al. 2012) and conservation psychology (Clayton and Myers 2015) have arisen in recent years, as a growing numbers of social scientists specialize in environmental or biodiversity conservation. Indeed, the Society for Conservation Biology established a Social Science Working Group in 2003 (http://conbio.org/groups/working-groups/socialscience), and a recent report from the Group provides an excellent introduction to the conservation social sciences (Bennett and Roth 2015). 
I advocate that if we are to be effective in tackling the human dimensions of bat conservation, we need to work collaboratively with scientists who understand and study people in the same depth that we do our bats! But communication across disciplines requires some measure of reciprocal understanding of the theory and practice of each discipline. The goal of this chapter is to facilitate conversation and collaboration with conservation social scientists. As is clear from Bennet and Roth (2015), there are many fields within the broad realm of conservation social science, but my aim is to introduce bat biologists to the core theoretical constructs behind behavior as applied to conservation and to report on empirical studies of human-bat relationships in these frameworks. Arguably, this task should have been left to a social scientist, but I hope that a natural scientist's perspective of the field may help make it accessible to my fellow bat biologists, who share my training, and avoid bias toward particular world views prevailing within the field. Nonetheless, the basic premise of the chapter is as follows:

very soon it will be unforgiveable to carry out second-rate social science in conservation, just as now it is unacceptable to use shoddy methods to monitor animal abundance (St John et al. 2013, pp. 357-358)

\subsection{Theories of Behavior and Behavioral Change}

People make behavioral choices based in large part on their values, attitudes, and to conform to societal expectations and pressures. Although early models of behavior assumed linear relationships in which knowledge influences attitude which in turn influences behavior relating to an issue of concern ("deficit" models-Burgess et al. 1998), this has rarely proved to be the case. Although the correlation between attitudes and behavior (Kraus 1995), including pro-environmental behavior, is quite well supported (Iozzi 1989), the relationship between knowledge and attitudes is complex and support variable (Kellert and Westervelt 1984; Kaiser et al. 1999; Kollmuss and Agyeman 2002; Thompson and Mintzes 2002). Providing people with knowledge about bats and logical arguments about the importance of addressing threats to them does not always change attitudes, and if it does, there is no guarantee that the attitude change will affect behavior toward them.

Psychologists came to appreciate that knowledge is just one of many factors influencing attitudes and recognized that external constraints and/or context (Guagnano et al. 1995; Stern 2000) may further influence changes in behavior. These concepts were encapsulated by the work of Martin Fishbein and Icek Ajzen who first added two factors to the simple linear pathway from attitude to behavior in the theory of reasoned action (TRA) (Fishbein and Ajzen 1975; Ajzen and Fishbein 1980). The theory of reasoned action proposes that the effects of attitudes on behavior are indirect and that there is an intermediate predictor of behaviorbehavioral intention. Behavioral intention is not only predicted by attitude but also by subjective norms - the perceived social pressure to perform or not perform the 


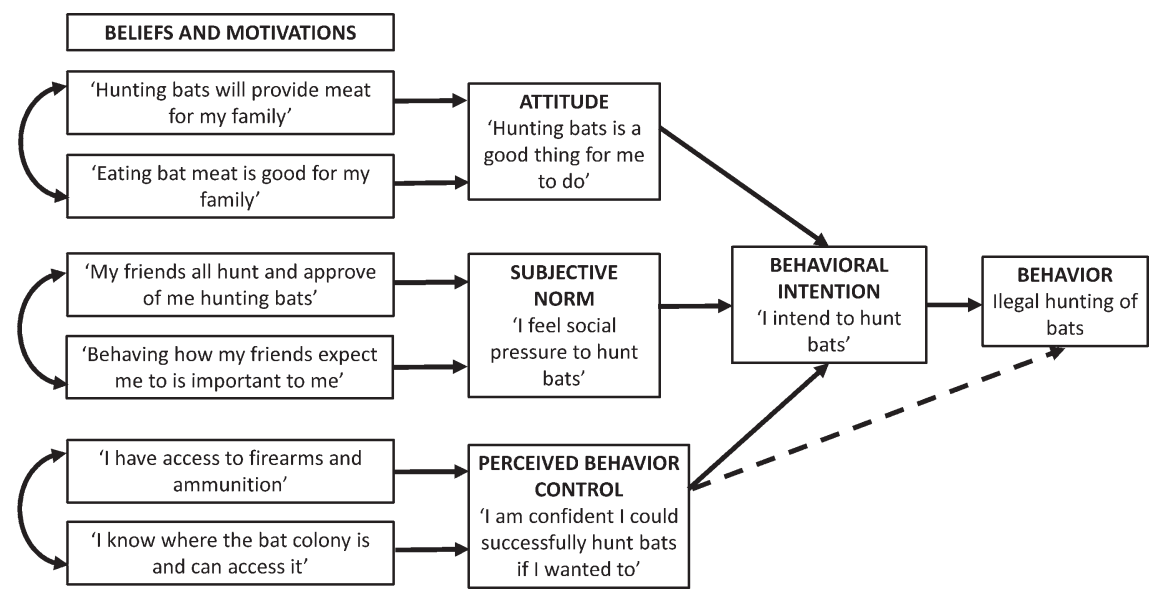

Fig. 18.1 The theory of planned behavior applied to illegal hunting of bats, for example Pteropus vampyrus in Sarawak, Malaysia. The strength of the components (attitude, subjective norms, and perceived behavioral control) and the beliefs that underpin them can be measured through interviews or questionnaires that ask respondents their level of agreement with the example statements. This not only provides the overall probability of a behavior, but also identifies the differential influence of the components and thus targets for intervention (adapted from St John et al. 2010, 2014)

behavior. The theory of planned behavior (TPB) added a third factor, perceived behavioral control, to the model. Perceived behavioral control describes whether or not people feel they have the resources, opportunities, or abilities to perform the relevant behavior (Azjen 1991) and can directly influence behavioral intention or the behavior itself (Fig. 18.1). Although the TPB has been a mainstay of attitudebehavior theory and research since its introduction and has received substantial empirical support (Armitage and Conner 2001), the application of the TPB to conservation is more recent (St John et al. 2010, 2013).

A related conceptual framework with a more specific history in environmental conservation and attitudes toward wildlife, particularly in the USA, is the value attitude behavior (VAB) model (Homer and Kahle 1988; Manfredo 2008). The VAB model places values at the base of a cognitive hierarchy of behavior, influencing attitudes and norms through a "value orientation." Values are defined as the set of beliefs held by an individual about what is right and wrong.

The power of these theories for practitioners aiming to induce behavioral change is that the target behavior is broken down into components which may differ in influence (St John et al. 2013) (Fig. 18.1). From a conservation perspective, analysis of the differential influences can help identify the most important barrier to change that can then be the focus of an intervention. So although attitudes are strong predictors of behavioral intention, they are commonly shaped by values, and the significance of subjective norms and perceived behavioral control in the success or otherwise of conservation interventions is becoming increasingly 
apparent (St John et al. 2013). But just what are these components? What do social scientists mean by values, attitudes, and norms, particularly as they relate to conservation and environmental behaviors?

\subsection{Values}

\subsubsection{Theory}

Values are fundamental beliefs about how the world should be, and they express a personal or social preference for an end state of existence or specific mode of conduct (Rokeach 1973). For example, people may value the end states of beauty, peace, wealth, friendship, equality, freedom (Rokeach 1973), and behaviors that can lead to these end states, e.g., self-expression, egalitarianism, belongingness, and humanity toward other living organisms. Values are single beliefs that form slowly in youth over many experiences (Rohan 2000). Consequently, they are stable through time, providing motivational constructs that persist through adulthood (Schwartz 1992), and are thus likely to strongly influence attitudes and guide an individual's processing of information and events.

There is a strong cultural component to values, so values tend to vary less within than they do among different cultures (Kluckhohn and Strodtbeck 1961; Schwartz 1992). Values are thought to be organized into value systems or value orientations (Rokeach 1973), and prioritization of values within these orientations is more individual and appears to explain differences among people in conservation-related attitudes and behaviors within cultures (Teel et al. 2015). Although values of an individual rarely change, they can change across generations as cultural expectations change through time (Manfredo and Teel 2008).

\subsubsection{Empirical Values}

Given the stability and motivational influence of values, much research has focused on identifying core values or sets of values that influence attitudes toward conservation and wildlife. A central hypothesis guiding this research is that, because of the commonalities of challenges that humans face across cultures, there should be a limited set of universal values (Kluckhohn and Strodtbeck 1961). Kluckhohn and Strodtbeck (1961) identified and tested six dimensions of cultural value orientations, one of which addressed the relationship of individuals and groups with nature. Human-nature relations fell into one of three orientations: mastery, in which humans are seen as superior to nature and have a need and responsibility to attempt to control it; harmony, whereby people work with nature to maintain harmony and balance; and subjugation, in which people cannot and should not exercise control over natural forces but, rather, are subject to the higher power of these 
forces. The influence of this foundational work persists, with value orientations that affect attitudes and behaviors more specifically toward wildlife variably described as mutualism/harmony/protection orientation versus materialism/domination/mastery/utilization (e.g., Fulton et al. 1996; Manfredo and Teel 2008).

Later influential work by Rokeach (1973) identified at most 36 universal values addressing all aspects of life, but most current conceptual frameworks have their origins in the theoretical structure for life values of Schwartz (1992). Schwartz proposed a typology of ten motivational life value types, comprising 56 value items, clustered along two motivational dimensions: openness to change versus conservation (meaning conservative behavior) and self-enhancement (e.g., materialism, personal ambition) versus self-transcendence (e.g., benevolence, respect for the environment) (Schwartz 1992), and these have proved remarkably consistent across cultures (Schwartz and Sagiv 1995; Schultz et al. 2005). Pro-environmental behaviors tend to correlate positively with self-transcendence values (Stern et al. 1998; Stern 2000).

While values can be hard to influence and change, there has been recent interest in their use in communication strategies intended to motivate conservation behavior (Clayton et al. 2013; Teel et al. 2015). "Deep framing" forges connections between the kind of language used in communication materials and a set of values (Crompton 2010). This approach is central to the "Common Cause" network of NGOs led by WWF-UK (http://valuesandframes.org/) seeking social and environmental change (Crompton 2010). The "Common Cause for Nature" publications comprise a detailed report and a practitioner's guide (Blackmore et al. 2013a, b) commissioned by 13 UK conservation organizations, including the Bat Conservation Trust. The reports focus on the ways in which values can be engaged as part of conservation communication. Schwartz's value topology is adopted, although grouped into "intrinsic" and "extrinsic" motivational clusters, which are broadly equivalent to self-transcendence (selfdirection, benevolence, universalism) and self-enhancement (power and achievement), respectively. Blackmore et al. (2013a, b) caution strongly against the use of extrinsic frames that "sell" the conservation issue. They argue that by framing conservation messages in terms of economic or utilitarian value, campaigns appeal to self-interest motivations and may suppress environmental concern. Rather, messaging should appeal to intrinsic values which are more likely to foster environmental concern. This is a pertinent consideration as many bat conservation frames are based on ecosystem services provided by bats, and there are a growing number of studies attaching monetary values to the services (e.g., Cleveland et al. 2006; Wanger et al. 2014).

\subsection{Attitudes}

\subsubsection{Theory}

Attitude describes the tendency to think, feel, or act positively or negatively toward objects in our environment (Eagly and Chaiken 1993). Tendency arises because of "an association, in memory, of an evaluation of an object" 
(Fazio et al. 1982, p. 341). Whereas values are single beliefs that transcend objects and situations and apply across time, attitudes organize several beliefs around a specific object or situation (Rokeach 1973). In the prevailing multicomponent model of attitude, attitudes are evaluations of an object that comprise three distinct components (Zanna and Rempel 1988; Eagly and Chaiken 1993). The cognitive component encompasses the beliefs and thoughts a person holds about an attitude object and the attributes they associate with it. Whereas bat researchers typically have a positive cognitive response to bats, a member of the public's belief in myths (alternative conceptions) may lead to negative responses and hence attitudes (Prokop and Tunnicliffe 2008; Prokop et al. 2009). The affective component describes the emotions a person feels toward an attitude object. Many people report that bats make them feel scared (e.g., Kahn et al. 2008); they have a negative affective response which can lead to a negative attitude. The behavioral component refers to past behaviors or experiences regarding an attitude object. The multicomponent model of attitude content is informative for educational approaches. As scientists we disdain emotional approaches to research, but this should not bleed into a solely cognitive approach to attitude change. While our training conditions us to address the cognitive component of an attitude, for example by providing information on ecosystem services, or attempting to dispel myths, appealing to affective components and behavioral components may be just as powerful (Pooley and O’Connor 2000) (Sect. 18.4.2.1).

It is also worth noting that an attitude object (bats) may not necessarily hold all three components. For example, a child present at a school visit may hold beliefs about bats and feel positively (or negatively) toward them, but have never encountered them (no behavioral component). Moreover, although associations among components are commonly consistent and even synergist in supporting a particular attitude (Eagly and Chaiken 1993), they can sometimes be inconsistent and even contradictory. This is critical to recognize in the design of conservation messages and interventions. For example, it is possible that someone is aware of and appreciates the ecosystem services that bats provide (positive cognition), but still fears them (negative affect), or has a long history of hunting and eating bats (negative behavior). Thus, appealing to single attitude component will not necessarily lead to a change in attitude, particularly if the other components are stronger. Materials and approaches that are themselves multicomponent may be more effective. For example, the Malaysian Bat Conservation Research Unit produced a comic "Gema's Home" (Benton-Browne and Palmer 2003), a story of an insectivorous bat, Gema (Malay for echo), whose tree roost was being cut down by a local farmer (Mr. Aziz). Gema's distress is palpable, and she appeals to her human friend, a little girl called Nur, for help. Nur and Gema take Mr. Aziz to visit a nectarivorous bat (Polly) and a fruit bat (Fruity), and together they explain the ecosystem services provided by bats and dispel some of the common myths about bats. Mr. Aziz changes his ways and becomes a protector of bats. The cartoon representations and characterizations of the bats are appealing (affective component), and Gema's situation is initially upsetting (affective), but there is explanation of 
the importance of bats (cognitive). The story is also produced as a shadow puppet show, a traditional performance art in Malaysia, as part of a children's workshop.

Attitudes and attitude components have both valence (positive vs. negative direction of evaluation) and strength. Attitude strength is an important consideration for interventions because strong attitudes are more likely to persist over time, resist change, influence information processing, and predict behavior (Petty and Krosnick 1995; Krosnick and Petty 1995; Holland et al. 2002).

Attitudes are believed to be adaptive, providing a rapid means for processing information and guiding behavior in a complex, data-laden environment and serving four broad functions (Smith et al. 1956; Katz 1960; Maio and Haddock 2014). Awareness of attitude functions is important from a conservation education perspective, because function, like the strength of the components described above, influences susceptibility to attitude change and the kinds of persuasive appeals that might work. First, attitudes can provide an object-appraisal function - a summary of the positive and negative attributes of an object to guide how a person should respond to it. Appraisals are commonly based on a utilitarian evaluation-bats provide ecosystem services as agents of pest control, or bats are great bushmeat, but may also derive from a feeling - bats are scary, or bats are cute. Second, attitudes can be used to convey our personal moral values and goals. This value-expressive function is related to our self-concept, and, perhaps not surprisingly, attitudes serving this function tend to be central and strong. Attitudes that facilitate relationships with others serve a social-adjustment function. Attitudes can also function to protect us against internal conflict (ego-defensive or externalization) and to defend our self-esteem (for further discussion see Maio and Haddock 2014).

By way of example, let us consider possible attitude functions toward colonies of flying foxes. Attitudes may be based on a utilitarian object-appraisal function in communities who view the bats as a source of bushmeat or income to feed their families (e.g., Kamins et al. 2014). In other communities, such as the Minahasa and Sangir tribes of northern Sulawesi, flying fox consumption may also be associated with a cultural identity (e.g., Sheherazade and Tsang 2015). Now, the attitude function may be value-expressive or social-adjustment. Contrasting attitudes toward the same bats held by biologists may be based on a utilitarian objectappraisal—bats are pollinators and seed dispersers, bats are sources of viruses that may affect human populations, and/or a deeply held belief that bats have a right to exist and not be hunted (value-expressive function). Value-expressive (core moral values and convictions) and object-appraisal functions seem especially predictive of behavior (Fazio 2000) and resistant to change. For example, Kamins et al. (2014) asked Ghanaian bat hunters and vendors what value bats have for people. Four responses were given-no value (14\%), economic value (30\%), meat (30 \%), and both meat and money (26\%), reflecting a highly utilitarian objectappraisal function for their attitude toward bats. A subsequent education intervention highlighting the disease risk associated with hunting and butchering bats and the environmental importance of fruit bats had only modest influence-only $45 \%$ of interviewees reported an intention to stop hunting, butchering, or selling bat bushmeat (Kamins et al. 2014). 
Because of the adaptive role attitudes play in dealing with the barrage of information we face every day, not only do they influence behavioral intention, but they also influence how we process information about the attitude object. This is important to be aware of in educational or outreach programs. Attitudes influence what information we pay attention to (selective exposure) (Allport 1935; Frey 1986), with preference for information that fits our existing evaluation (KnoblochWesterwick and Meng 2009); how we evaluate the new information, especially if our existing attitude is strong and hence accessible (Houston and Fazio 1989); and our ability to remember specific information (selective memory) or behaviors. In general, information processing works to minimize cognitive dissonance (Festinger 1957) — the sense of disquiet or mental tension we feel if our behavior or beliefs toward an object are inconsistent. So there is a tendency to select, evaluate, and remember information congruent with our attitudes (otherwise, we have trouble believing in ourselves). In the vernacular, we can think of this as "preaching to the converted" or having our information "fall on deaf ears."

\subsubsection{Empirical Attitudes Toward Animals and Factors Affecting Them}

The most widely used framework for understanding people's attitudes toward animals (rather than other environmental issues more generally) remains the empirical approach of Stephen Kellert. Kellert led a five-phase report to the US Department of Interior, Fish and Wildlife Service (1977-1983) evaluating the US public's knowledge and attitudes toward animals through surveys of 3945 members of the public (Kellert 1979, 1980; Kellert and Berry 1980; Kellert and Westervelt 1981, 1983). His findings suggested that four major factors influence the US public's attitudes to animals: (i) prior attitude toward, and values of wildlife and nature; (ii) previous experience and knowledge of species or group; (iii) relationship between species and humans, e.g., cultural significance, utility value, or conservation status; and (iv) human perceptions of individual species.

Kellert's work lacked a clear conceptual framework (Manfredo 2008), so below I try to integrate some of the more theoretical perspectives that have since been developed and then examine how we might view these factors from the perspective of bat conservation initiatives and outreach. As detailed below, bats are a mix of good news and bad news when viewed in the context of Kellert's framework.

\subsubsection{Prior Attitudes and Values of Wildlife and Nature}

Kellert developed a typology of attitudes to wildlife (Kellert 1976, 1993, 2002) and identified nine groups, the most common of which were humanistic (primary interest in and strong affection for individual animals, principally pets), moralistic (primary concern for the right and wrong treatment of animals, with strong 
opposition to exploitation of and cruelty toward animals), utilitarian (primary concern for the practical and material value of animals), and negativistic (primary orientation an active avoidance of animals due to dislike or fear) (Kellert 1980; Kellert and Wilson 1993). In a similar vein, but starting from a theoretical standpoint, Stern and colleagues used Schwartz's work on values (Sect. 18.3.2) to develop a value-based theory of environmental attitudes, describing them as egoistic (reflecting concern about environmental problems for the self), altruistic (concern for the effect on others, such as friends, family, community, and future generations), and biospheric (concern for living things regardless of their value to people) (Stern and Dietz 1994; Stern et al. 1993). Later authors collapse these attitudes to simply anthropocentric (utilization) and biocentric (preservation) (e.g., Milfont and Duckitt 2010). Other motivational frameworks place additional emphasis on the role of emotions (Pooley and O'Connor 2000; Serpell 2004).

Knight (2008) found that people with higher moralistic attitudes report higher levels of support for protection of species (including bats) than those with dominionistic world views. Interestingly, moral reasoning and moralistic attitudes toward animals and nature can develop as early as preschool in children (Kahn 2006), and moral concern and caring can exist alongside a fear orientation (Kahn et al. 2008), the basis for negativistic attitudes. Kahn et al. (2008) interviewed children in four age groups (6-7 years, 9-10 years, 12-13 years, and 15-16 years) as they exited an exhibit of Rodrigues fruit bats (Pteropus rodricensis) at Brookfield Zoo (Illinois, USA) and explored caring for bats, fear of bats, and potential moral basis for keeping bats (or not) in captivity. The exhibit presented no barriers between visitors and the bats (glass or mesh), permitting potentially "fearful" encounters as bats swooped by. While just over half the children, especially in the younger age groups, expressed some fear, the same fearful children still cared about bats and the rights of bats. All children gave both anthropocentric and biocentric justifications in response to questions about caring for bats and the rights of bats.

Unfortunately, fear (Prokop et al. 2009) and disgust for bats (Prokop and Tunnicliffe 2008) are widespread. In a study across UK, India, USA, Holland, Korea, Hong Kong, and Japan, bats fell firmly into the "disgust" category falling behind cockroaches, spiders, beetles, maggots, worms, and leeches, and only just beating out wasps, lizards, rats, mice, and slugs (Davey et al. 1998)! Bats are recognized and conceptualized as "bad" animals even among kindergarteners (Kubiatko 2012). Rachman (1977) proposed that fears are learned by children through one of a combination of the following learning pathways: (1) direct conditioning, (2) vicarious learning, and (3) negative verbal information. The power of negative verbal information in engendering fear of novel animals has been demonstrated (Field and Lawson 2008) and is especially effective when verbal information comes from a parent (Muris et al. 2010; Remmerswaal et al. 2013). Conversely, there is a reduction in children's fear beliefs when positive information is provided about novel animals (Field and Lawson 2003; Muris et al. 2003; Kelly et al. 2010). However, fear beliefs can be difficult to reverse if they are already well established, rather than invoked toward a novel animal. Williams (2014) sought to reduce fear of bats in US 7- to 9-year-olds with positive verbal 
information. Although she found a slight change in scores on the Bat Attitude Questionnaire in some children, there were no significant changes in scores on the Fear Belief Questionnaire. Few children will have encountered bats by this age, so direct acquisition of fear through classical conditioning is unlikely. Rather, William's study illustrates just how powerful the indirect negative information coming from the media and culture can be in defining children's fear of bats, and this will be particularly pronounced if conveyed by parents.

If positive information, which is tackling the cognitive component of attitude, is ineffective in changing attitudes, perhaps we would do better to work on the affective component. When an object is paired with an affective sensation, we are tapping into emotion learning, or affective or evaluative conditioning (De Houwer et al. 2001), similar to the classical condition of Pavlov, more familiar to biologists. Although evaluative conditioning is strongest when people have low knowledge about the attitude object, it can still influence attitude change when knowledge or attitudes exist (Olson and Fazio 2006). Bats are frequently paired with scary, negative emotions (e.g., vampires, horror films, haunted houses), so we must work to link positive affect to them. Outreach activities should be fun and participatory: For example, the MBCRU refers to a 3-h children's workshop as the "Malaysian Bat Party" with activities and games that children enjoy. Another approach is to look beyond our rationalist scientific training and promote empathy for bats by levering the universal human tendency to anthropomorphize (project human characteristics onto non-human animals). Anthropomorphism may have been with us since Paleolithic times (Mithen and Boyer 1996), and its use as tool for conservation is receiving growing attention (Tam et al. 2013; Chan 2012; RootBernstein et al. 2013). Anthropomorphic bats already prevail in the children's bat literature, led by Jane Cannon's wonderful Stellaluna, although bats in some books lack names and in others look like rodents! From a campaign perspective, probably the earliest example of deliberate anthropomorphic characterization of bats comes from the work of the UK's Mammal Society and the Fauna and Flora Preservation Society to change attitudes to bats when they received full legal protection under Wildlife and Countryside Act in 1981. Artist Guy Troughton deliberately portrayed bats as friendly, fun creatures in books, stickers (Fig. 18.2), mugs, and Christmas cards, and these products were integral to the reversal of public attitudes to bats (Morris 1987).

\subsubsection{Previous Experience and Knowledge}

As nocturnal, volant mammals, people do not experience bats in the way that they might birds and this has consequences for attitudes. Bat sightings are commonly at a distance and fleeting (Sexton and Stewart 2007), while closer encounters may be in a negative or fearful setting, for example as a nuisance in dwellings (Voigt et al. 2016), and/or may prompt fears of disease(Liesener et al. 2006). Bat knowledge is commonly low (e.g., Kingston et al. 2006; Sexton and Stewart 2007; Sheherazade and Tsang 2015) and correlates with attitudes toward bats (Prokop et al. 2009). 
Fig. 18.2 Car sticker from the campaign to change the attitudes of the British public to bats c. 1985. Artist Guy

Troughton subtly altered the bat to confer greater anthropomorphic appeal (large, soulful eyes and a slightly tremulous smile!) (Source Morris 1987)

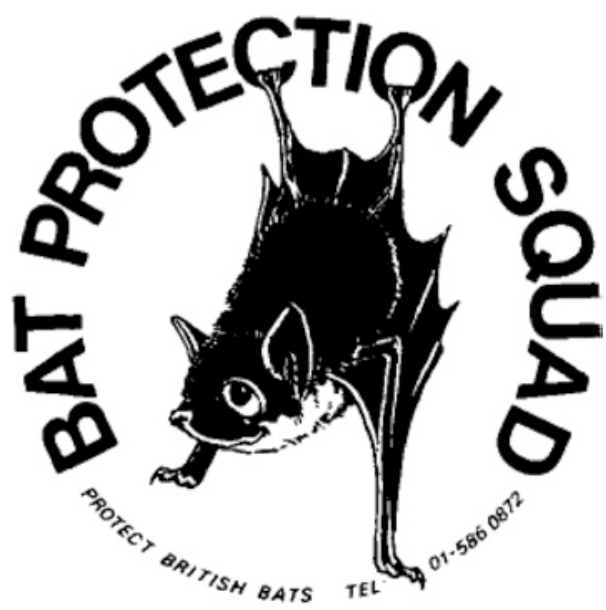

Moreover, outreach must operate not just from a position of limited or no knowledge, but contend with the abundance of "alternative conceptions" or myths about bats. For example, only $17 \%$ of nearly 200 children (6-16 years) surveyed by Prokop and Tunnicliffe (2008) in Slovakia rejected the idea that bats can tangle in human hair and $36 \%$ asserted that the main diet of bats is blood, a misconception that was still prevalent in undergraduates (Prokop et al. 2009). Not only do alternative conceptions about bats correlate with negative attitudes, but alternative conceptions are depressingly robust and difficult to correct (Mintzes and Wandersee 1998).

It is a rare for a bat biologist to complete a school visit without encountering the "bats lay eggs" question (or assertion!). Viewed through the lens of cognitive psychology, the paucity of knowledge about bats means that many lay people conceptualize them as an exception to the rule "if it has wings, it is a bird." Consequently, they are more likely to use knowledge of the behavior and physiology of birds to reason about bats than they would other mammals (e.g., dogs and hedgehogs) (Davis et al. 2013). Davis et al. asked subjects the likelihood that an internal trait (a protein) and a behavioral trait (a feeding behavior) described in birds or mammals would also be found in bats and dogs. People were significantly more likely to generalize the bird traits to bats than dogs and the mammal traits to dogs than bats. So non-experts automatically assume that the knowledge they have about birds applies to bats and vice versa. This is of conservation concern because bats share little behaviorally or physiologically with birds and respond differently to conservation issues.

\subsubsection{Relationship Between Species and Humans-Cultural Significance and Utility Value}

Conceptions of nature are a social construct created within a historical and cultural context (Clayton and Myers 2015). It is beyond the scope of this chapter to review all the cultural, religious, and symbolic perspectives of bats(see Lawrence 
1993), but around the world, bats are commonly associated with aspects of death and sometimes rebirth. For example, bats are believed to be witches in Nigeria (Iroro Tanshi, pers. comm.), spirits of the dead in the Ivory Coast, criminals in Madagascar (Andrade 2009), and souls of the dead searching for rebirth in old Europe. They are deified in Mayan culture, although the bat god Camazotz is thought to represent some kind of giant vampire bat, and is still associated with death, unfortunately. More broadly, while the Bible describes bats as detestable, unclean birds (Leviticus 11:13-20, Deuteronomy 14:11-19), in Shi'a hadith (Nahjul Balagha Sermon 154 or 155 depends on the version), bats are viewed as a testament to "His [Allah's] delicate production, wonderful creation and deep sagacity." Famously, in Chinese, culture bats are viewed as auspicious creatures and symbols of good luck because the word "bat" is a homophone (pronounced the same) of "fortune" in Mandarin Chinese. The Wu Fu, or five lucks, is typically depicted as a ring of five bats signifying the Five Fortunes-longevity, wealth, health and composure, virtue, and a natural death in old age.

On the plus side, bats have great utility to people through the ecosystem services they provide as agents of pest suppression, pollination and seed dispersal, and sources of guano (Kunz et al. 2011). Boyles et al. (2011) estimated that bats may collectively save the US agricultural industry at least $\$ 3.7$ billion a year by suppressing crop pests, and Wanger et al. (2014) put the value of a single insecteating species (Chaerephon plicata) to rice production in Thailand at over $\$ 1$ million annually. Such economic evaluations certainly receive substantial press coverage, and it would be interesting to study the influence of this on public attitudes toward bats. Caution is warranted because while featuring ecosystem services can be an effective frame for a campaign, attaching monetary evaluations to wildlife appeals to materialist values which may evoke values and attitudes that are less receptive to conservation (see 18.3.2 above).

\subsubsection{Human Perceptions of Individual Species}

Public support for species' conservation is strongly influenced by human perceptions, predominantly the esthetic appeal of the species (Gunnthorsdottir 2001; Stokes 2007), its similarity to humans (Kellert 1996; Batt 2009), and perceived threat to humans (Knight 2008; Kellert 1996). Unfortunately, to much of the public, bats have little esthetic appeal (Knight 2008) and frequently evoke disgust (Davey et al. 1998; Bjerke and Østdahl 2004) and, despite being mammals, bear very little similarity to humans ("where are its eyes?"). Even well-meaning educational displays may feed rather than extinguish these perceptions, particularly when imagery is at a larger-than-life scale (Fig. 18.3).

Perceptions of the threats of bats to people are becoming a major concern because of the, often alarmist, publicity surrounding their role as reservoir hosts in emerging infectious diseases (Schneeberger and Voigt 2016). This requires careful treatment in education programs because although the likelihood of a bat virus being transmitted to humans is very low, the consequences of infection can 
Fig. 18.3 Some portrayals of bats in education settings can have a counterproductive influence on attitudes and perceptions (Photo T. Kingston)

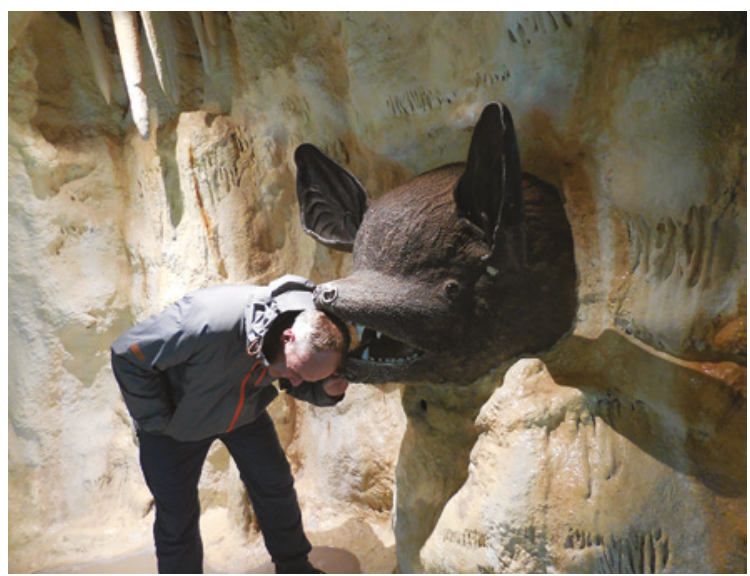

be very high, often fatal. In many countries, populations at risk of exposure, such as bat hunters, butchers, consumers, or guano harvesters, have very low rates of risk perception (Harrison et al. 2011; Robertson et al. 2011; Kamins et al. 2014). Educational interventions are needed to reduce target behaviors that increase transmission probabilities, but the challenge from a conservation perspective is to do so without engendering an overall negative attitude toward bats or calls for destruction of populations. Education materials that simultaneously target behaviors and highlight bat ecosystem services are a start (see Appendix 3 of Kamins et al. 2014), but it is unclear how effective these approaches are, and further research on such "mixed messages" is much needed.

\subsection{Social Norms}

Although the social norm concept has its origins in early twentieth century anthropology and sociology (Hechter and Opp 2001) and was explicitly incorporated into the TRA and TPB (as the subjective norm), recognition of the role of the social context and pressures on people's attitude and behavior toward environmental actions and species protection is more recent (Cialdini et al. 1990; Cialdini 2003; Mascia et al. 2003; Schultz et al. 2007; Goldstein et al. 2008; St John et al. 2013; McDonald et al. 2014).

Social norms are the accepted or implied rules about how members of a social group should, and do, behave (Sherif 1936). Individuals breaking these rules may be sanctioned formally, if the norm is written into law for example, or informally through social disapproval. The more motivated an individual is to identify with a particular social group, the more likely they are to recognize and conform to the group's norms (Deaux 1996; Manfredo 2008), particularly if the norm is central to group identification (Christensen et al. 2004). Social norms are dynamic, and 
they depend on the person and situation (Ajzen 1971). There are several norm constructs, beginning with the subjective norm of Fishbein and Ajzen (1975) which focuses on beliefs about what important others expect one to do in a given situation. A more operational approach identifies the descriptive norm, which is based on perceptions about what others actually do, and the injunctive norm, perceptions about what others approve of (more akin to the original subjective norm) (Cialdini and Trost 1998). This division is important because appeals in which these conflict can fail to change behavioral intention (Cialdini 2003, McDonald et al. 2014). So if a persuasive appeal is intending to convey disapproval of an action (injunctive norm), but at the same time suggests that many people perform this behavior (descriptive norm), the message is normatively muddled. For example, if a message was to indicate that people should not kill bats (perhaps by hunting, or excluding them from homes) (injunctive norm) but that many people are doing so (descriptive norm), the persuasive appeal is conflicted. If there are high levels of a socially disapproved behavior, it is better to focus on the injunctive norm. Conversely, a descriptive norm approach would be effective in promoting a new behavior, for example building bat houses. In sum, descriptive and injunctive normative messages need to align and whenever possible be used together (Cialdini 2003; Kinzig et al. 2013).

Sociology identifies four basic types of norms: folkways or "customs"; mores-norms of morality including religious doctrines; taboos-behaviors forbidden by culture (which may be enacted into law); and laws-norms that are written down and enforced. The potential of taboos, and the informal institutions that proscribe them, to advance conservation agendas is of growing interest (Colding and Folke 2001), particularly in situations where the influence of external formal institutions is constrained (Jones et al. 2008). Taboos prohibit eating of bats (Pteropus) by the Mahafaly and Antandroy people of Madagascar (MacKinnon et al. 2003), while sacred forests provide protection in other parts of the country (Rahaingodrahety et al. 2008). Similarly, sacred groves protect colonies of Pteropus giganteus in Tamil Nadu, India (Marimuthu 1988; Tangavelou et al. 2013), and West Kalimantan, Indonesia (Wadley and Colfer 2004). Colonies of Pteropus throughout much of Indochina are associated with gardens attached to Buddhist monasteries (pers. obs.), while sacred caves protected by Buddhists provide refuge for diverse insectivorous bat species (e.g., Robinson and Smith 1997). Sacred caves and rocks provide similar protection elsewhere with known examples from Ghana (Hens 2006) and Kenya (Metcalfe et al. 2009).

People do not always adhere to taboos or mores, or practice their nominal religion, especially if there is conflict with utilitarian or cultural use of the animal. For example, although all the Abrahamic religions explicitly prohibit consumption of bats, sales and consumption of flying foxes in North Sulawesi peak around Christian celebrations (Sheherazade and Tsang 2015). Similarly, taboos may not be respected if wildlife resources are scare (Bobo et al. 2015). In addition, bats may be seen as the exception to broader social norms. For example, India's Wildlife Protection Act (1972) schedules bats as vermin, excluding them from 

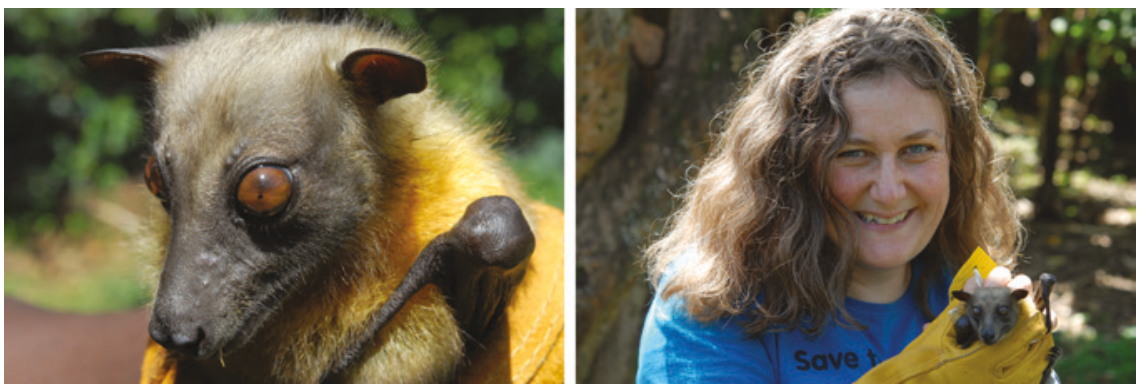

Fig. 18.4 Portrait of Eidolon helvum, typical of bat biologists' collections (Photo T. Kingston) (left) and the author smiling with the same bat (right) conveying positive affect that can shape social norms and attitudes toward bats (Photo P. Webala)

protection. Nonetheless, appealing to neglected prior norms and taboos may be a point of leverage, but should be done with guidance from local religious/spiritual leaders.

Norms are internalized by three transmission routes (Gintis 2003), vertically from parent to child, obliquely through social institutions (e.g., religion, government, school, media), and horizontally through interactions with peers. Conveyance methods (Cialdini and Trost 1998) include active instruction (stories, myths), passive observation (nonverbal imitation), and inference from behavior around us. Bat researchers can contribute to the oblique transmission route of positive social norms about bats by publicizing their work in the popular scientific press, social media, visiting schools, etc. To be effective, we should be sure to emphasize the wonder of bats, not just our science, and not be afraid to appeal to emotion and anthropomorphic tendencies (Sect. 18.4.2.2). As biologists, when photographing bats we tend to concentrate our efforts on portraiture (head shots), to capture the diversity of bat morphology and diagnostic taxonomic features, or "researchers in action," conveying only a scientific behavioral norm toward bats which often involves trapping of some description. These have their place, but from an outreach perspective intending to lever norms, images of a researcher holding a bat smiling conveys that bats are not a source of fear but happiness (positive affect) and that many people do, and one should, behave positively toward them (Fig. 18.4).

\subsection{Assessing Attitudes, Values, and Norms}

From the above, it is clear that knowledge of people's values, attitudes, attitude functions, and social norms could be very useful in the design of messages aimed at influencing behavior. A detailed review of methods for measuring these psychosocial constructs is beyond the scope of this chapter, but for conservation 
purposes, most measures are commonly based on self-reporting (or interviews) through questionnaires with scaled responses. Good questionnaires can gather information on knowledge, values, attitudes, opinions, behaviors, facts, and other information and have been increasingly used in ecology and conservation biology to assess stakeholder opinions and perceptions of and behaviors toward species or issues of conservation concern (White et al. 2005). Although many of us have designed and given questionnaires to or interviewed stakeholders, robust design that can evaluate the values and attitudes behind behaviors and provide an unbiased assessment of the behaviors themselves requires substantial preparation. Central is a solid theoretical understanding of social psychology and psychometrics and design considerations. For example, questionnaires need to quantify and maximize validity (does the questionnaire or "instrument" measure what it intended to) and reliability (does the instrument consistently or accurately measure what it is intended to measure). The procedure for sampling the target population (e.g., random, systematic, comprehensive) needs to be considered as does nonresponse bias, to name but a few factors.

Measuring behavior through self-reporting or interviews can be particularly tricky if the behavior is illegal or contravenes a social norm (socially disapproved or inappropriate). Respondents may not tell the truth or may skip the question, compromising data validity (King and Bruner 2000). This is key if the prevalence of particular behaviors (such as hunting bats) is the end point of the study and is even more pertinent if the study aims to assess whether attitudes are good predictors of behavior (e.g., St John et al. 2011). Recent applications of sensitive question tools from human health research (e.g., condom use in HIV research) to conservation "rule breaking" provide much higher reporting of illegal activities than conventional approaches (St John et al. 2013; Nuno and St John 2015). If non-sensitive characteristics (attitudes or demographics) can predict sensitive behaviors, then the identification of the target audience for intervention is greatly facilitated (St John et al. 2013).

Scientists are rarely trained in appropriate social science methodologies and indeed may come at human studies from a very different philosophical perspective that can influence our understanding and interpretation of social science data and conclusions (Moon and Blackman 2014). As emphasized in the introduction, we should be collaborating directly with social scientists (Mascia et al. 2003; Sandbrook et al. 2013; St John et al. 2014), but a good introduction to methods is given in Newing (2011).

\subsection{Recommendations}

There remain few published studies addressing the drivers of human behavior toward bats, yet this is key to their conservation. The primary recommendation for bat biologists directly tackling bat conservation issues is to work with conservation social scientists to fully characterize the human dimension of the problem and 
identify targets for intervention. Key considerations in the design of interventions and messages are as follows:

- Work to establish the component (value, attitude, norm, perceived behavioral control) of the TPB pathway/VAB framework acting as a barrier to behavioral change. Target the "barrier component" for intervention.

- Recall that many components are structured. Attitudes may be based on cognitive, affective, or behavioral perspectives, and attitude functions serve different roles. If interventions are to resonate with a target audience, it is critical that they not only address the component that is the problem, but that the message matches the content or functions that are the basis for the recipients' attitude. Similarly, social norms can be descriptive or injunctive, and messages should be sure to align with the prevailing norm and avoid conflict between them.

- Work with values and avoid framing messages that appeal to extrinsic or selfenhancement values.

- Remember that much of human behavior is driven by how we feel (affective component of attitudes, social pressure behind norms). Do not be afraid to appeal to emotion and anthropomorphic tendencies in the design of messages and materials.

- Be aware of our influence as scientists on social norms relating to bats and be sure to convey the wonder and positive affect they engender (BATS ARE COOL!!!).

Open Access This chapter is distributed under the terms of the Creative Commons Attribution Noncommercial License, which permits any noncommercial use, distribution, and reproduction in any medium, provided the original author(s) and source are credited.

\section{References}

Abdul Aziz S, Olival KJ, Bumrungsri S, Richards GC, Racey PA (2016) The conflict between fruit bats and fruit growers: species, legislation and mitigation. In: Voigt CC, Kingston $\mathrm{T}$ (eds) Bats in the Anthropocene: conservation of bats in a changing world. Springer International AG, Cham, pp 377-420

Ajzen I (1971) Attitudinal vs. normative messages: an investigation of the differential effects of persuasive communications on behavior. Sociometry 34:263-280

Ajzen I (1991) The theory of planned behavior. Organ Behav Hum Dec 50:179-211

Ajzen I, Fisbein M (1980) Understanding attitudes and predicting social behavior. Prentice-Hall, Englewood Cliffs

Allport GW (1935) Attitudes. In: Murchison C (ed) Handbook of social psychology. Clark University Press, Worcester, MA, pp 798-844

Altringham J, Kerth G (2016) Bats and roads. In: Voigt CC, Kingston T (eds) Bats in the Anthropocene: conservation of bats in a changing world. Springer International AG, Cham, pp 35-58

Andrade E (2009) Bats. In: Asante MK, Mazama A (eds) Encyclopedia of African Religion, vol 1. Sage, Thousand Oaks, pp 113-114

Armitage CJ, Conner M (2001) Efficacy of the theory of planned behaviour: a meta-analytic review. Brit J Soc Psychol 40:471-499 
Arnett EB, Baerwald EF, Matthews F, Rodrigues L, Rydell J, Voigt CC (2016) Impacts of wind energy development on bats: a global perspective. In: Voigt CC, Kingston T (eds) Bats in the Anthropocene: conservation of bats in a changing world. Springer International AG, Cham, pp 295-317

Batt S (2009) Human attitudes towards animals in relation to species similarity to humans: a multivariate approach. Biosci Horiz 2:180-190

Bennett NJ, Roth R (eds) (2015) The conservation social sciences: What? How? and Why? Canadian Wildlife Federation and Institute for Resources, Environment and Sustainability, University of British Columbia, Vancouver, BC

Benton-Browne A, Palmer E (2003) Gema's Home. Produced by the Malaysian Bat Conservation Research Unit and available for download http://www.seabcru.org/wp-content/ uploads/2013/07/Comic-Gemas-Home.pdf

Bjerke T, Østdahl T (2004) Animal-related attitudes and activities in an urban population. Anthrozoös 17:109-129

Blackmore E, Underhill R, McQuilkin J, Leach R (2013a) Common cause for nature: finding values and frames in the conservation sector. Public Interest Research Centre, Machynlleth, Wales

Blackmore E, Underhill R, McQuilkin J, Leach R, Holmes T (2013b) Common cause for nature: a practical guide to values and frames in conservation. Public Interest Research Centre, Machynlleth, Wales

Bobo KS, Aghomo FFM, Ntumwel BC (2015) Wildlife use and the role of taboos in the conservation of wildlife around the Nkwende Hills Forest Reserve; South-west Cameroon. J Ethnobiol Ethnomed 11:1-24

Boyles JG, Cryan PM, McCracken GF, Kunz TH (2011) Economic importance of bats in agriculture. Science 332:41-42

Burgess J, Harrison CM, Filius P (1998) Environmental communication and the cultural politics of environmental citizenship. Environ Plann A 30:1445-1460

Chan AAH (2012) Anthropomorphism as a conservation tool. Biodiv Conserv 21:1889-1892

Christensen PN, Rothgerber H, Wood W, Matz DC (2004) Social norms and identity relevance: A motivational approach to normative behavior. Pers Soc Psychol B 30:1295-1309

Cialdini RB (2003) Crafting normative messages to protect the environment. Curr Dir Psychol Sci 12:105-109

Cialdini RB, Trost MR (1998) Social influence: social norms, conformity, and compliance. In: Gilbert DT, Fiske ST, Lindzey G (eds) The handbook of social psychology, 4th edn. McGraw Hill, Boston, pp 141-192

Cialdini RB, Reno RR, Kallgren CA (1990) A focus theory of normative conduct: recycling the concept of norms to reduce littering in public places. J Pers Soc Psychol 58:1015-1026

Clayton S, Myers OE (2015) Conservation psychology: understanding and promoting human care for nature, 2nd edn. Wiley-Blackwell, Chichester

Clayton S, Litchfield C, Geller ES (2013) Psychological science, conservation, and environmental sustainability. Front Ecol Environ 11:377-382

Cleveland CJ, Betke M, Federico P, Frank JD, Hallam TG, Horn J et al (2006) Economic value of the pest control service provided by Brazilian free-tailed bats in south-central Texas. Front Ecol Environ 4:238-243

Colding J, Folke C (2001) Social taboos: 'Invisible' systems of local resource management and biological conservation. Ecol Appl 11:584-600

Crompton T (2010) Common Cause: The case for working with our cultural values. WWF, Surrey

Davey GC, McDonald AS, Hirisave U, Prabhu GG, Iwawaki S, Im Jim C et al (1998) A crosscultural study of animal fears. Behav Res Ther 36:735-750

Davis T, Goldwater MB, Gaylord N, Worthy DA, Otto AR, Glass BD (2013) The cognitive psychology of human-bat interactions: Implications for ecological policy and zoonotic disease transmission. In: Geyer GA (ed) Bats: phylogeny and evolutionary insights, conservation strategies and role in disease transmission. Nova, Hauppauge, pp 1-17 
De Houwer J, Thomas S, Baeyens F (2001) Association learning of likes and dislikes: a review of 25 years of research on human evaluative conditioning. Psychol Bull 127:853-869

Deaux K (1996) Social identification. In: Higgins ET, Kruglanski AW (eds) Social psychology: handbook of basic principles. The Guildford Press, New York, pp 777-798

Decker DJ, Riley SJ, Siemer WF (eds) (2012) Human dimensions of wildlife management. John Hopkins University Press, Baltimore

Eagly AH, Chaiken S (1993) The psychology of attitudes. Harcourt, Brace and Jovanovich, San Diego

Ehrlich P, Kennedy D (2005) Millennium assessment of human behaviour. Science 309:562-563

Fazio RH, Chen J, McDonel EC, Sherman SJ (1982) Attitude accessibility, attitude-behavior consistency, and the strength of the object-evaluation association. J Pers Soc Psychol 47:277-286

Fazio RH (2000) Accessible attitudes as tools for object appraisal: their costs and benefits. In: Maio GR, Olson JM (eds) Why we evaluate: functions of attitudes.Erlbaum, Mahwah, pp 1-36

Festinger L (1957) A theory of cognitive dissonance. Standford University Press, Stanford

Field AP, Lawson J (2003) Fear information and the development of fears during childhood: Effects on implicit fear responses and behavioural avoidance. Behav Res Ther 41:1277-1293

Field AP, Lawson J (2008) The verbal information pathway to fear and subsequent causal learning in children. Cogn Emot 22:459-479

Fishbein M, Ajzen I (1975) Belief, attitude, intention, and behavior: an introduction to theory and research. Addison-Wesley, Reading

Frey D (1986) Recent research on selective exposure to information. In: Berkowitz L (ed) Advances in experimental social psychology, vol 19. Academic Press, San Diego, pp 41-80

Fulton DC, Manfredo MJ, Lipscomb J (1996) Wildlife value orientations: a conceptual and measurement approach. Hum Dimens Wildl 1:24-47

Furey NM, Racey PA (2016) Conservation ecology of cave bats. In: Voigt CC, Kingston T (eds) Bats in the Anthropocene: conservation of bats in a changing world. Springer International AG, Cham, pp 463-492

Gintis H (2003) Solving the puzzle of prosociality. Ration Soc 15:155-187

Goldstein NJ, Cialdini RB, Griskevicius V (2008) A room with a viewpoint: Using social norms to motivate environmental conservation in hotels. J Consum Res 35:472-482

Guagnano GA, Stern PC, Dietz T (1995) Influences on attitude-behavior relationships: A natural experiment with curbside recycling. Environ and Behav 27:699-718

Gunnthorsdottir A (2001) Physical attractiveness of an animal species as a decision factor for its preservation. Anthrozoös 14:204-215

Harrison ME, Cheyne SM, Darma F, Ribowo DA, Limin SH, Struebig MJ (2011) Hunting of flying foxes and perception of disease risk in Indonesian Borneo. Biol Conserv 144:2441-2449

Hechter M, Opp KD (2001) Social norms. Russell Sage Foundation, New York

Hens L (2006) Indigenous knowledge and biodiversity conservation and management in Ghana. J Hum Ecol 20:21-30

Holland R, Verplanken B, van Knippenberg A (2002) On the nature of attitude-behavior relations: the strong guide, the weak follow. Eur J Soc Psychol 32:869-876

Homer PM, Kahle LR (1988) A structural equation test of the value-attitude-behavior hierarchy. J Pers Soc Psychol 54:638-647

Houston DA, Fazio RH (1989) Biased processing as a function of attitude accessibility: making objective judgments subjectively. Soc Cognition 7:51-66

Iozzi LA (1989) What research says to the educator: part one, environmental education and the affective domain. J Environ Educ 20:3-9

Jones JPG, Andriamarovololona MM, Hockley N (2008) The importance of taboos and social norms to conservation in Madagascar. Conserv Biol 22:976-986

Jung K, Threlfall CG (2016) Urbanisation and its effects on bats-a global meta-analysis. In: Voigt CC, Kingston T (eds) Bats in the Anthropocene: conservation of bats in a changing world. Springer International AG, Cham, pp 13-28 
Kahn PH (2006) Nature and moral development. In: Killen M, Smetana JG (eds) Handbook of moral development. Lawrence Erlbaum Associates, Mahwah, pp 461-480

Kahn PH, Saunders CD, Severson RL, Myers OE, Gill BT (2008) Moral and fearful affiliations with the animal world: children's conceptions of bats. Anthrozoös 21:375-386

Kamins AO, Rowcliffe JM, Ntiamoa-Baidu Y, Cunningham AA, Wood JL, Restif O (2014) Characteristics and risk perceptions of Ghanaians potentially exposed to bat-borne zoonoses through bushmeat. EcoHealth 12:104-120

Katz D (1960) The functional approach to the study of attitudes. Public Opin Quart 24:163-204

Kaiser FG, Wölfing S, Fuhrer U (1999) Enviornmental attitude and ecological behavior. J Environ Psychol 19:1-19

Kellert SR (1976) Perceptions of animals in American society. Trans Nort Am Wildl Nat Res 41:533-546

Kellert SR (1979) Public attitudes toward critical wildlife and natural habitat issues, phase I. United States Department of the Interior Fish and Wildlife Service

Kellert SR (1980) Phase II: Activities of the American public relating to animals. United States Department of the Interior Fish and Wildlife Service

Kellert SR (1993) The biological basis for human values of nature. In: SR Kellert, EO Wilson (eds) The biophilia hypothesis. Island Press, Washington, DC, pp 41-69

Kellert SR (1996) The value of life: biological diversity and human society. Island Press, Washington

Kellert SR (2002) Experiencing nature: affective, cognitive, and evaluative development in children. In: Kahn PH, Kellert SR (eds) Children and nature: psychological, sociocultural, and evolutionary investigations. MIT Press, Cambridge, pp 117-151

Kellert SR, Berry JK (1980) Phase III: Knowledge, affection and basic attitudes toward animals in American society. United States Department of the Interior Fish and Wildlife Service

Kellert SR, Westervelt MO (1981) Trends in animal use and perception in twentieth century America: Phase IV. United States Department of the Interior Fish and Wildlife Service

Kellert SR, Westervelt MO (1983) Children's attitudes, knowledge and behaviors toward animals: Phase V. United States Department of the Interior Fish and Wildlife Service

Kellert SR, Westervelt MO (1984) Children's attitudes, knowledge and behaviors towards animals. Children's Environs Quart 1:8-11

Kellert SR, Wilson EO (1993) The biophilia hypothesis. Island Press, Washington, DC

Kelly VL, Barker H, Field AP, Wilson C, Reynolds S (2010) Can Rachman's indirect pathways be used to unlearn fear? A prospective paradigm to test whether children's fears can be reduced using positive information and modelling a non-anxious response. Behav Res Ther 48:164-170

King MF, Burner GC (2000) Social desirability bias: a neglected aspect of validity testing. Psychol Market 17:79-103

Kingston T, Juliana S, Rakhmad SK, Fletcher CD, Benton-Browne A, Struebig M et al (2006) The Malaysian Bat Conservation Research Unit: Research, capacity building and education in an Old World hotspot. In: Sahir O, Siti Hawa Y, Sivananthan E, Shukor Md. N, Norhayati A, Sharul Anuar Mohd. S (eds) Proceedings of the national seminar on protected areas. Department of Wildlife and National Parks, Malaysia, pp 41-60

Kinzig AP, Ehrlich PR, Alston LJ, Arrow K, Barrett S, Buchman TG et al (2013) Social norms and global environmental challenges: the complex interaction of behaviors, values, and policy. Bioscience 63:164-175

Kluckhohn FR, Strodtbeck FL (1961) Variations in value orientations. Row, Peterson, Oxford

Knight AJ (2008) "Bats, snakes and spiders, Oh my!" How aesthetic and negativistic attitudes, and other concepts predict support for species protection. J Environ Pyschol 28:94-103

Knobloch-Westerwick S, Meng J (2009) Looking the other way: selective exposure to attitudeconsistent and counterattitudinal political information. Commun Res 36:426-448

Kollmuss A, Agyeman J (2002) Mind the Gap: why do people act environmentally and what are the barriers to pro-environmental behavior? Environ Educ Res 8:239-260 
Korine C, Adams R, Russo D, Fisher-Phelps M, Jacobs D (2016) Bats and water: anthropogenic alterations threaten global bat populations. In: Voigt CC, Kingston T (eds) Bats in the Anthropocene: conservation of bats in a changing world. Springer International AG, Cham, pp 215-233

Kraus SJ (1995) Attitudes and the prediction of behaviour: a meta-analysis of the empirical literature. Pers Soc Psychol B 21:58-75

Krosnick JA, Petty RE (1995) Attitude strength: an overview. In: Petty RE, Krosnick JA (eds) Attitude strength: antecedents and consequences. Erlbaum, Hillsdale, pp 1-24

Kubiatko M (2012) Kindergarten children's perception of animals focusing on the look and fear of animals. Educ Sci: Theory Pract 12:3181-3186

Kunz TH, Braun de Torrez E, Bauer D, Lobova T, Fleming TH (2011) Ecosystem services provided by bats. Ann NY Acad Sci 1223:1-38

Law B, Park K, Lacki M (2016) Insectivorous bats and silviculture: balancing timber production and bat conservation. In: Voigt CC, Kingston T (eds) Bats in the Anthropocene: conservation of bats in a changing world. Springer International AG, Cham, pp 105-141

Lawrence EA (1993) The sacred bee, the filthy pig, and the bat out of hell: Animal symbolism as cognitive biophilia. In: Kellert SR, Wilson EO (eds) The biophilia hypothesis. Island Press, Washington, DC, pp 301-341

Liesener AL, Smith KE, Davis RD, Bender JB, Danila RN, Neitzel DF et al (2006) Circumstances of bat encounters and knowledge of rabies among minnesota residents submitting bats for rabies testing. Vector Borne Zoonotic Dis 6:208-215

MacKinnon JL, Hawkins CE, Racey PA (2003) Pteropodidae, fruit bats, Fanihy, Angavo. In: Goodman SM, Benstead JP (eds) The natural history of Madagascar. University of Chicago Press, Chicago, pp 1299-1302

Maio GR, Haddock G (2014) The psychology of attitudes and attitude change, 2nd edn. Sage, Los Angeles

Manfredo MJ (ed) (2008) Who cares about wildlife? Social science concepts for exploring human-wildlife relationships and conservation issues. Springer, New York

Manfredo MJ, Teel TL (2008) Integrating concepts: demonstration of a multilevel model for exploring the rise of mutualism value orientations in post-industrial society. In: Manfredo MJ (ed) Who cares about wildlife? Social science concepts for exploring human-wildlife relationships and conservation issues. Springer, New York, pp 191-218

Marimuthu G (1988) The sacred flying fox of India. Bats 6:10-11

Mascia M, Brosius JP, Dobson TA, Forbes B, Horowitz L, McKean M, Turner N (2003) Conservation and the social sciences. Conserv Biol 17:649-650

McDonald RI, Fielding KS, Louis WR (2014) Conflicting social norms and community conservation compliance. J Nat Conserv 22:212-216

Menon V, Lavigne D (2006) Attitudes, values and objectives: the real basis of wildlife conservation. In: Lavigne DM (ed) Gaining ground: In pursuit of ecological sustainability. International Fund for Animal Welfare and University of Limerick, Guelph and Limerick, pp 173-189

Metcalfe K, French-Constant R, Gordon I (2009) Sacred sites as hotspots for biodiversity: the Three Sisters Cave complex in coastal Kenya. Oryx 44:118-123

Meyer CFJ, Struebig MJ, Willig MR (2016) Responses of tropical bats to habitat fragmentation, logging, and deforestation. In: Voigt CC, Kingston T (eds) Bats in the Anthropocene: conservation of bats in a changing world. Springer International AG, Cham, pp 63-94

Milfont TL, Duckitt J (2010) The environmental attitudes inventory: a valid and reliable measure to assess the structure of environmental attitudes. J Environ Psychol 30:80-94

Mildenstein T, Tanshi I, Racey PA (2016) Exploitation of bats for bushmeat and medicine. In: Voigt CC, Kingston T (eds) Bats in the Anthropocene: conservation of bats in a changing world. Springer International AG, Cham, pp 325-363

Mintzes JJ, Wandersee JH (1998) Research in science teaching and learning: a human constructivistic view. In: Mintzes JJ, Wandersee JH, Novak JD (eds) Teaching science for understanding. Academic Press, Orlando, pp 59-92 
Mithen S, Boyer P (1996) Anthropomorphism and the evolution of cognition. J Roy Anthropol Inst 2:717-721

Moon K, Blackman D (2014) A guide to understanding social science research for natural scientists. Conserv Biol 28:1167-1177

Morris PA (1987) Changing attitudes towards British mammals. Biol J Linn Soc 32:225-233

Muris P, Bodden D, Merckelbach H, Ollendick TH, King N (2003) Fear of the beast: a prospective study on the effects of negative information on childhood fear. Behav Res Ther 41:195-208

Muris P, van Zwol L, Huijding J, Mayer B (2010) Mom told me scary things about this animal: parents installing fear beliefs in their children via the verbal information pathway. Behav Res Ther 48:341-346

Newing H (2011) Conducting research in conservation: social science methods and practice. Routledge, New York

Nuno A, St John FA (2015) How to ask sensitive questions in conservation: a review of specialized questioning techniques. Biol Conserv 189:5-15

Olson MA, Fazio RH (2006) Reducing automatically activated prejudice through implicit evaluative conditioning. Pers Soc Psychol B 32:421-433

Petty RE, Krosnick JA (eds) (1995) Attitude strength: antecedents and consequences. Erlbaum, Hillsdale

Pooley JA, O'Connor M (2000) Environmental education and attitudes: emotions and beliefs are what is needed. Environ Behav 32:711-723

Prokop P, Tunnicliffe SD (2008) "Disgusting" animals: primary school children's attitudes and myths of bats and spiders. Eurasia J Math Sci Tech Ed 4:87-97

Prokop P, Fančovičová J, Kubiatko M (2009) Vampires are still alive: Slovakian students' attitudes towards bats. Anthrozoös 22:19-30

Rachman S (1977) The conditioning theory of fear-acquisition a critical examination. Behav Res Ther 15:375-387

Rahaingodrahety VN, Andriafidison D, Ratsimbazafy JH, Racey PA, Jenkins RK (2008) Three flying fox (Pteropodidae: Pteropus rufus) roosts, three conservation challenges in southeastern Madagascar. Madagascar Conserv Develop 3:17-21

Remmerswaal D, Muris P, Huijding J (2013) "Watch out for the gerbils, my child!" The role of maternal information on children's fear in an experimental setting using real animals. Behav Ther 44:317-324

Robertson K, Lumlertdacha B, Franka R, Petersen B, Bhengsri S, Henchaichon S et al (2011) Rabies-related knowledge and practices among persons at risk of bat exposures in Thailand. PLoS Negl Trop Dis 5(6):e1054

Robinson MF, Smith AL (1997) Chiroptera from Loei Province, north-east Thailand. Nat Hist B Siam Soc 45:1-16

Rohan MJ (2000) A rose by any name? The values construct. Pers Soc Psychol Rev 4:255-277

Rokeach M (1973) The nature of human values, vol 438. Free Press, New York

Root-Bernstein M, Douglas L, Smith A, Verissimo D (2013) Anthropomorphized species as tools for conservation: utility beyond prosocial, intelligent and suffering species. Biodivers Conserv 22:1577-1589

Rowse EG, Lewanzik D, Stone EL, Harris S, Jones G (2016) Dark matters: the effects of artificial lighting on bats. In: Voigt CC, Kingston T (eds) Bats in the Anthropocene: conservation of bats in a changing world. Springer International AG, Cham, pp 187-207

Sandbrook C, Adams WM, Buescher B, Vira B (2013) Social research and biodiversity conservation. Conserv Biol 27:1487-1490

Schneeberger K, Voigt CC (2016) Zoonotic viruses and conservation of bats. In: Voigt CC, Kingston T (eds) Bats in the Anthropocene: conservation of bats in a changing world. Springer International AG, Cham, pp 263-282

Schultz PW (2011) Conservation means behaviour. Conserv Biol 25:1080-1083

Schultz PW, Gouveia VV, Cameron LD, Tankha G, Schmuck P, Franěk M (2005) Values and their relationship to environmental concern and conservation behavior. J Cross Cult Psychol 36:457-475 
Schultz PW, Nolan JM, Cialdini RB, Goldstein NJ, Griskevicius V (2007) The constructive, destructive, and reconstructive power of social norms. Psychol Sci 18:429-434

Schwartz SH (1992) Universals in the content and structure of values: theoretical advances and empirical tests in 20 countries. Adv Exp Soc Pyschol 25:1-65

Schwartz SH, Sagiv L (1995) Identifying culture-specifics in the content and structure of values. J Cross Cult Psychol 26:92-116

Serpell JA (2004) Factors influencing human attitudes to animals and their welfare. Anim Welfare 13(suppl. 1):145-151

Sexton NR, Stewart SC (2007). Understanding knowledge and perceptions of bats among residents of Fort Collins, Colorado. US Geological Survey

Sheherazade, Tsang SM (2015) Quantifying the bat bushmeat trade in North Sulawesi, Indonesia, with suggestions for conservation action. Global Ecol Conserv 3:324-330

Sherif M (1936) The psychology of social norms. Harper \& Brothers, New York

Smith MB, Bruner JS, White RW (1956) Opinions and personality. Wiley, New York

St John FAV, Edwards-Jones G, Jones JPG (2010) Conservation and human behavior: lessons from social science. Wild Res 37:658-667

St John FAV, Keane AM, Edwards-Jones G, Jones L, Yarnell RW, Jones JP (2011) Identifying indicators of illegal behaviour: carnivore killing in human-managed landscapes. Proc R Soc Lond B Bio rspb20111228

St John FAV, Keane AM, Milner-Gulland EJ (2013) Effective conservation depends upon understanding human behaviour. In: MacDonald DW, Willis KJ (eds) Key topics in conservation biology, vol 2. Wiley-Blackwell, Colchester, pp 344-361

St John FAV, Keane AM, Jones JPG, Milner-Gulland EJ (2014) Robust study design is as important on the social as it is on the ecological side of applied ecological research. J Appl Ecol $51: 1479-1485$

Stern PC (2000) Toward a coherent theory of environmentally significant behavior. J Soc Issues 3:407-424

Stern PC, Dietz T (1994) The value basis of environmental concern. J Soc Issues 50:65-84

Stern PC, Dietz T, Kalof L (1993) Value orientations and environmental concern. Environ Behav 25:322-348

Stern PC, Dietz T, Guagnano GA (1998) A brief inventory of values. Educ Psychol Meas 58:984-1001

Stokes DL (2007) Things we like: human preferences among similar organisms and implications for conservation. Hum Ecol 35:361-369

Tam KP, Lee SL, Chao MM (2013) Saving Mr. Nature: anthropomorphism enhances connectedness to and protectiveness toward nature. J Expt Soc Psychol 49:514-521

Tangavelou AC, Rani PJ, Karthikeyan S (2013) Conservation of Sacred Indian flying fox (Bat) at sacred landscape of Pudukottai district, Tamil Nadu, India. Asian J Conserv Biol 2:178-180

Teel LT, Dietsch AM, Manfredo MJ (2015) A (social) psychology approach in conservation. In: Bennett NJ, Roth R (eds) The conservation social sciences: What? How? and Why? Canadian Wildlife Federation and Institute for Resources, Environment and Sustainability. University of British Columbia, Vancouver, pp 21-25

Thompson TL, Mintzes JJ (2002) Cognitive structure and the affective domain: on knowing and feeling in biology. Int J Sci Educ 24:645-660

Veríssimo D (2013) Influencing human behavior: an underutilised tool for biodiversity management. Conserv Evid 10:29-31

Voigt CC, Kingston T (2016) Bats in the Anthropocene: conservation of bats in a changing world. Springer International AG, Cham

Voigt CC, Phelps KL, Aguirre LF, Schoeman MC, Vanitharani J, Zubaid A (2016) Bats and buildings: the conservation of synanthropic bats. In: Voigt CC, Kingston T (eds) Bats in the Anthropocene: conservation of bats in a changing world. Springer International AG, Cham, pp 427-453

Wadley RL, Colfer CJP (2004) Sacred forest, hunting and conservation in West Kalimantan, Indonesia. Hum Ecol 32:313-338 
Wanger TC, Darras K, Bumrungsri S, Tscharntke T, Klein AM (2014) Bat pest control contributes to food security in Thailand. Biol Conserv 171:220-223

White PCL, Jennings NV, Renwick AR, Barker NHL (2005) Questionnaires in ecology: a review of past use and recommendations for best practice. J Appl Ecol 42:421-430

Williams KJ (2014) The effect of positive verbal information on reducing fears about bats in school-aged children. PhD Dissertation, UMI Number 3618417, Walden University, USA

Williams-Guillén K, Olimpi E, Maas B, Taylor PJ, Arlettaz R (2016) Bats in the anthropogenic matrix: challenges and opportunities for the conservation of Chiroptera and their ecosystem services in agricultural landscapes. In: Voigt CC, Kingston T (eds) Bats in the Anthropocene: conservation of bats in a changing world. Springer International AG, Cham, pp 151-178

Zanna MP, Rempel JK (1988) Attitudes: a new look at an old concept. In: BarTal D, Kruglanski AW (eds) The social psychology of knowledge. Cambridge University Press, Cambridge, pp 315-334 